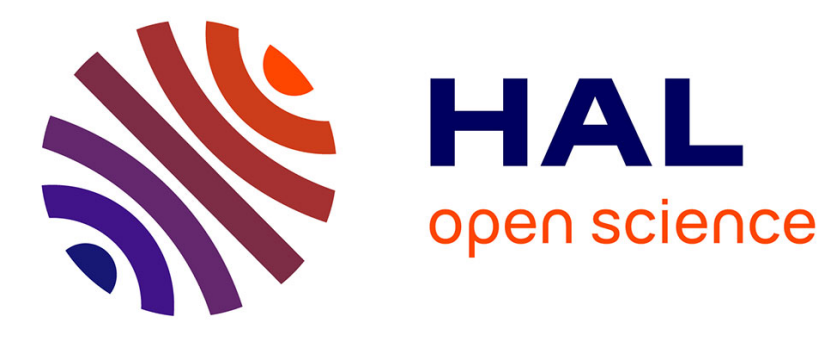

\title{
Typifying ecosystems by using green lacewing assemblages
}

\author{
Dominique Thierry, Bruno Deutsch, Mihaela Paulian, Johanna Villenave, \\ Michel Canard
}

\section{- To cite this version:}

Dominique Thierry, Bruno Deutsch, Mihaela Paulian, Johanna Villenave, Michel Canard. Typifying ecosystems by using green lacewing assemblages. Agronomy for Sustainable Development, 2005, 25 (4), pp.473-479. hal-00886302

\section{HAL Id: hal-00886302 https://hal.science/hal-00886302}

Submitted on 1 Jan 2005

HAL is a multi-disciplinary open access archive for the deposit and dissemination of scientific research documents, whether they are published or not. The documents may come from teaching and research institutions in France or abroad, or from public or private research centers.
L'archive ouverte pluridisciplinaire HAL, est destinée au dépôt et à la diffusion de documents scientifiques de niveau recherche, publiés ou non, émanant des établissements d'enseignement et de recherche français ou étrangers, des laboratoires publics ou privés. 


\title{
Typifying ecosystems by using green lacewing assemblages
}

\author{
Dominique ThIERRY ${ }^{\mathrm{a} *}$, Bruno DeUTSCH${ }^{\mathrm{b}}$, Mihaela PAULIAN ${ }^{\mathrm{c}}$, Johanna VILLENAVE ${ }^{\mathrm{d}}$, Michel CANARD \\ ${ }^{a}$ Université Catholique de l'Ouest, Département des Sciences de la Vie et de la Terre, 44 rue Rabelais, 49000 Angers, France \\ ${ }^{\mathrm{b}}$ Université Catholique de l'Ouest, Institut de Mathématiques Appliquées, 3 place André Leroy, 49000 Angers, France \\ ${ }^{\mathrm{c}}$ Institutul de Cercetari pentru Protectia Plantelor, Bd. Ion Ionescu dela Brad 8, 77592 Bucuresti, Romania \\ d Institut National d'Horticulture, Unité de Protection des Plantes, 2 rue Le Nôtre, 49045 Angers Cedex 01, France \\ e (retired) 47 chemin Flou de Rious, 31400 Toulouse, France
}

(Accepted 20 May 2005)

\begin{abstract}
Green lacewing collection data from eleven various biotopes were used to typify different ecological landscapes. To make up the values recorded on single samples, we operated by the bootstrap method. A classifying process cluster scatterplot was then established to assess the proximity of the different habitats. Shannon's and Hurlbert's indices are highly sensitive parameters of the structure of assemblages. Their analysis results in a diagrammatic typological approach to the biotopes, allowing unambiguous comparisons between various chrysopid assemblages. It is possible to characterize the state of these polyvalent predators as a function of different abundance and diversity, and this state can be a standard of value of good ecological function in ecosystems. Concerning farming consultation and environmental conservation, such an approach is new and could be promising for future agricultural and landscape managers.
\end{abstract}

biodiversity / green lacewing / faunistic richness / diversity index / equitability index

\section{INTRODUCTION}

The relation between the repair of biocoenoses and the species diversity they harbor is a well-known notion. Increasing biodiversity generally enhances the reliability of ecosystems, i.e. the probability that a system will provide a consistent level of performance over a given unit of time (Naeem and Li, 1997). Assessing agricultural ecosystems with respect to their current healthy condition and their ability to allow sustainable development is now a fundamental aim of scientists and advisors. Several authors (e.g. Stelzl and Devetak, 1999) assumed that Neuroptera constitute a standard of value useful for judging the good health of an agro-environment, even if a many-sided approach might be theoretically better (Duelli, 1997). Green lacewings occur commonly in many biotopes and they are easily identifiable to species level. The larvae of all species and adults of some of them are polyphagous predators on various soft-bodied arthropods: they are redundant in the sense of having multiple species per functional group (Lawton and Brown, 1993). Incidentally, they participate in controlling numerous phytophagous organisms. Among their usual prey there are noxious arthropods to crops, often key pests such as aphids, coccids, psyllids, cicadellids, caterpillars, mites and others.

Using value standards to characterize biodiversity is essential to quantify such a property and to compare various agricul- tural situations differing from one another by locality or time (Paulian et al., 2003). The aim of the present paper, based on several previous field surveys of chrysopid assemblages, is to assess the significance, the range and the accuracy of different indices. They are based on the analyses of biotopes diversely or unaltered by insecticide pressure and/or other compelling factors; they succeed in typifying ecological landscapes.

\section{MATERIALS AND METHODS}

\subsection{Methodology}

To analyze the structure of green lacewing assemblages, we chose to determine for each habitat three indices among the most commonly used in such quantitative descriptions of insect populations; namely, a species richness index proposed by Margalef $\left(\mathrm{I}_{\mathrm{M}}\right)$, plus two diversity indices proposed by Shannon $\left(\mathrm{H}^{\prime}\right)$ and by Hurlbert $\left(\mathrm{E}_{\mathrm{H}}\right)$.

For each sample, the observed values, i.e. collection data, were registered. Each index was estimated with the observed data. In order to evaluate the precision of the estimates we employed the bootstrap methods (Efron, 1982; Efron and Tibshirani, 1993). Following the classical procedure, we computed a large number of virtual samples $(10000)$ that were simulated by randomly collected sub-samples within an infinite

* Corresponding author: dominique.thierry@wanadoo.fr 
population holding the same distribution of species as the original sample (Manly, 1991). For each simulated sample, a "simulated index" was computed. Firstly, the standard deviations of the 10000 "simulated indices" were computed. Secondly, a 95\% confidence interval [CT1, CT2] was computed by the percentile method of Efron (1982) which we adapted slightly in the case of Margalef's index. In the general case, CT1 and CT2 are the 2.5 th and the 97.5 th percentile values of the distribution of the simulated indices. In the case of Margalef's index, the sub-samples cannot have more species than the original one, but may have less. So the upper bound CT2 of the interval would be the same as the estimated value of $\mathrm{I}_{\mathrm{M}}$. In order to assess the possible upper variability of the estimations, the upper bound CT2 was transformed into CT2' $=\mathrm{I}_{M}+\left(\mathrm{I}_{\mathrm{M}}-\right.$ CT1). This kind of symmetry transformation results in almost the same probability of finding a new species, as there is of missing one among the rarest species of the sample. A classifying process (Cluster Scatterplot) was established in order to assess the proximity of the different habitats. Data were statistically analyzed by using the Statgraph $®$ statistical graphic system (STSC Inc., Rockville, Maryland, USA).

\subsection{Biocoenotic richness}

The commonest way to characterize a group of organisms in a biotope consists of counting the number of specimens present, giving the abundance and the biomass of the target group. The specimens collected may be either grouped (Q) or shared out across all species $\left(\mathrm{q}_{\mathrm{i}}\right)$ then constituting the actual size of the various species. Another structural parameter is the taxonomic richness $(\mathrm{S})$, which equates to the number of species occurring in the biotope. Although these indicators are simple and easily available, caution is needed before their use and analysis. In some cases, the species status is indeed difficult to state precisely - e.g. in the Chrysoperla carnea (Stephens, 1836) complex - so that the actual abundance of every true species in some cases cannot be determined. Nevertheless, it is only from the two available parameters $S$ and $Q$ that we may assess representative biocoenotic indices.

Species richness is highly dependent upon the sample size. The optimal sample sizes are conventionally defined when the taxonomic richness reaches $95 \%$ of the theoretical value of $\mathrm{S}$. Increasing the sample size could, however, allow the rarest components of the fauna to be progressively included. There is a linear function between the number of species and the logarithm of the sample size:

$$
\mathrm{S}=\alpha \times \log \mathrm{Q}
$$

in which the gradient of the curve is related to the sample size. The taxonomic richness is featured as Margalef's index $\left(\mathrm{I}_{\mathrm{M}}\right)$, the lower limit of which is zero:

$$
\mathrm{I}_{\mathrm{M}}=(\mathrm{S}-1) / \log \mathrm{Q} .
$$

\subsection{Quantifying biodiversity}

Several indices can be used to characterize the biodiversity of a biotope. They indicate the taxonomic richness together with the assemblage structure; namely, the diversity of the species, the dominance and the equitability.

The standard Shannon's diversity index (H') proposed by Shannon and Weaver (1963) is largely used in ecological studies. It is only slightly correlated to the sample size. It gives both the relative importance of each species collected and the ratio between the total numbers of species and individuals. Its values range from 0 to $\log \mathrm{S}$, being maximal in stable ecosystems such as in spontaneous forests.

Hurlbert's equitability index $\left(\mathrm{E}_{\mathrm{H}}\right)$ measures the relative heterogeneity of populations. It features the distribution of the specimens occurring in an assemblage and gives an idea of the dominance of the more abundant species. This index is a priori well adapted to the study of small samples in which the ratio of the number of taxa related to the total size is fairly high (Beisel et al., 1997). It varies from 0 to 1 , being nil when the quasi-totality of the specimens caught belongs to a single species and reaches one when each species is represented by the same number of individuals.

\subsection{Biotopes and collecting methods}

Several previous biotope surveys were analyzed, belonging to various European ecosystems (Fig. 1).

\subsubsection{Flat open fields}

Flat open fields as typical agro-ecosystems under the Atlantic influence were investigated. The study was carried out in Loos-en-Gohelle, in the French southern part of the Flanders Plain, Pas-de-Calais, France (50 $27^{\circ} 00^{\prime}$ N, $\left.02^{\circ} 47^{\prime} 00^{\prime \prime} \mathrm{E}\right)$ (called LOO). It is a traditionally agricultural zone where vegetable and fruit production predominates. The target fields were of a commercial type, but managed with 'soft' cultural techniques: either integrated or strictly organic farming. Several crops: strawberry, potato, witloof, tobacco and kidney-bean and their neighboring uncultivated biotopes were sampled.

Various collection methods were used: suction trap, yellow traps and hand net. Adults were regularly sampled in the growing season (from May to October) of 1999 (Trouvé et al., 2002).

\subsubsection{Mediterranean olive groves}

Olive groves as characteristic agro-ecosystems of the Mediterranean region were studied. The first olive plantation was situated in Agistri island, Saronic gulf, Attiki, Greece ( $37^{\circ} 44^{\prime}$ $48^{\prime \prime} \mathrm{N}, 23^{\circ} 25^{\prime} 39^{\prime \prime} \mathrm{E}$ ) (AGU), which is located near the seashore, less than $20 \mathrm{~m}$ above sea level. It is of traditional dry farming so that it looks like a sub-spontaneous sparse Mediterranean forest. The trees were old, with a medium canopy, and were hardly or not maintained by farmers. Despite the aridity, hardy cereals or traditional spring leguminous plants under some of the biggest trees. Pesticide treatments were not applied, either to the olive trees or on the underlying crops. The surroundings constituted thermophilous shrubs (Code Natura 2000: 53.30) and Aleppo pine spontaneous forest (Code Natura 2000: 42.84) on the hillside, and untreated vineyards and fig trees on the seaside.

The green lacewings were collected by a series of 25 McPhail traps baited with 5\% bi-ammonium phosphate, emptied 


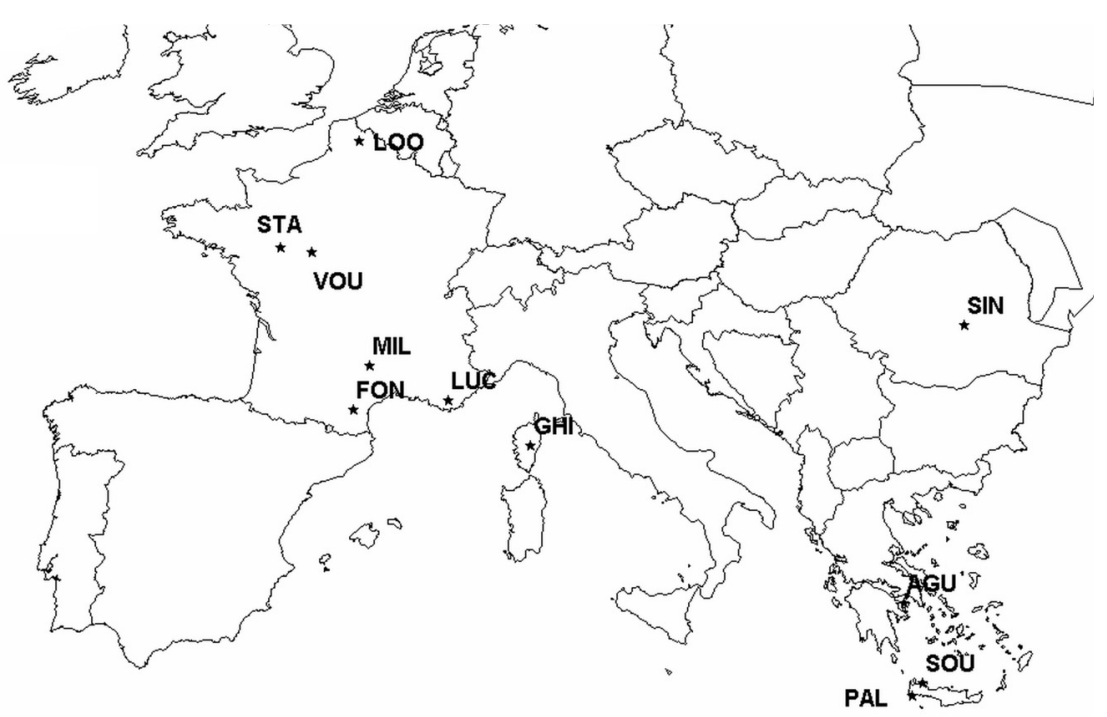

Figure 1. Collection sites of green lacewings in Europe. AGU = Aguistri, FON $=$ Fontcouverte, GHI $=$ Ghisoni, LOO $=$ Loos-en-Gohelle, MIL = Millau, PAL = Paleochora, SIN = Sinaia, SOU = Souda, STA = Saint-Aubin Island, VOU = Vouvray.

weekly for identification. The sampling period lasted from mid-July to October 1976 (Canard and Landého, 1977).

Two other olive orchards were situated in western Crete, Greece. One was in Paleochora in the southern coastal plain near the sea $\left(35^{\circ} 14^{\prime} 00^{\prime \prime} \mathrm{N}, 23^{\circ} 41^{\prime} 00^{\prime}\right.$ ' E) (PAL). It was irrigated and the ground was covered with alfalfa and natural grasses. The sampled area was bordered by cultures such as alfalfa, various vegetables and other olive orchards, with or without irrigation. The trees were treated with a soil application of an anti-olive-fly insecticide three or four times a year, between the beginning of June and the end of October. The other olive orchard was situated in Souda, in the northern coastal plain near the sea (35 29' 04' N, 24 04' 28' E) (SOU). It was an irrigated area where tomatoes and cucumbers were grown. The area borders on a stony hillside covered by sparse wild vegetation. The trees were treated against olive fly only three times a year in late summer and autumn, between 6 September and 21 October (Canard et al.,1979).

The adult lacewings were surveyed in the Cretan groves during two consecutive warm seasons, namely in August and September 1977, plus from May to September 1978. They were sampled using McPhail traps baited with Dacus bait ${ }^{\circledR}$ plus $1.5 \%$ borax for better preservation and collected weekly. In Souda the traps were emptied every two weeks, because 'sondage' was used as a second complementary method during the trapping-free weeks. Sondage consisted of a fog spray of decamethrin in diesel oil retained for half a minute into the canopy under a plastic sheet surrounding the tree; all insects which were knocked down were collected after 15 to 30 minutes on a fine plastic net placed under the tree before fogging (Neuenschwander et al., 1981).

The last olive grove was situated on a calcareous stony hilly ground in southern France, near Le Luc-en-Provence, Var,
France ( $43^{\circ} 23^{\prime} 00^{\prime}$ N, $06^{\circ} 19^{\prime} 00^{\prime}$ E) (LUC), situated at an altitude of about $250 \mathrm{~m}$. The grove was 15 years old and the trees were treated with an anti-olive-fly insecticide five or six times between July and the end of October, by means of baited traps. The upper plant level constituted a thick moorland vegetation of Spartium junceum, Cistus monspeliensis, Pistacia lentiscus and Pistacia terebenthus, and also the arboreal canopy of Pinus halepensis and Quercus lanuginosa contributed partially to the covering. The sides of the orchard adjacent to vineyards were regularly treated by usual viticultural pesticides.

Green lacewings were collected in a network of $20 \mathrm{McPhail}$ bottles (baited as mentioned above). The traps were visited every week, from the beginning of May to mid-October 1977 and 1978 (Alrouechdi et al., 1980).

\subsubsection{Natural wet plain meadowlands}

Samples were taken in the Loire Valley, which remains one of the last big complexes of rarely reaped European meadows (code Natura 2000: 65.10 and 64.30) (Corillon, 1995). This wetland zone has been designated for the purpose of the Ramsar convention (Anonymous, 2000). A first collecting was done near Vouvray, Indre-et-Loire, France ( $47^{\circ} 25^{\prime} 00^{\prime}$ ' N, $00^{\circ} 48^{\prime}$ 00" E) (VOU). This biotope, despite its Atlantic position, has thermophilous characteristics (Corillon, 1995). This low vegetation site lies about $300 \mathrm{~m}$ from the high river banks and extends into the whole flood plain. It comprises mainly grasses such as Alopecurus pratensis and Arrhenatherum sp. All these meadowlands were traditionally devoted to extensive grazing and hay-cutting; however, farming activity is in decline, so that no agricultural practice has been continued for more than five years. 
Insects were collected by day, by hand-net sweeping in low vegetation and beating the lower part of the canopy of the scattered bushes and trees, mainly Quercus pedunculata. Samples were taken from May to September 1999.

Another survey was carried out in the Saint-Aubin Island, in the Mayenne and the Sarthe valleys, near Angers, Maine-etLoire, France ( $\left.47^{\circ} 52^{\prime} 00^{\prime \prime} \mathrm{N}, 00^{\circ} 55^{\prime} 00^{\prime} \mathrm{W}\right)$ (STA). The arboreal vegetation mainly constitutes Fraxinus angustifolia and some Quercus pedunculata, associated with shrubs such as Prunus spp. The herbaceous stratum is diversified due to different flooding periods on the island, with Lolio cynosuretum associations under associated hordectosum and typicum, and a Thalictro-senecionetum association. Chrysopid adults were actively collected by day with a hand net in the vegetation. Collections were performed weekly from the beginning of June to the end of August 2001.

\subsubsection{Calcareous slopes}

A chrysopid survey was carried out in July 1995 and 1996, in a karstic region of southern France, near Millau, Aveyron, France ( $44^{\circ} 06^{\prime} 00^{\prime \prime} \mathrm{N}, 03^{\circ} 05^{\prime} 00^{\prime \prime} \mathrm{E}$ ) (MIL). The collecting places were a series of contrasted biocoenotic units whose vegetation cover showed a mosaic-like structure. They spread out from the plateau where a dry semi-natural lawn of Festuca spp. grew (code Natura 2000: 62.10), broken only by discontinued trees such as calcarophilous oaks (Qercus spp.), up to the shaded side of the Tarn valley crowded with chestnut trees (Castanea sativa) (code Natura 2000: 92.60).

Adult green lacewings were caught by day, by hand-net sweeping the low herbaceous layer, bushes and the lower tree foliage.

\subsubsection{Mediterranean forest}

This biotope investigated as a typical Mediterranean forest is a thermo-Mediterranean, spontaneous pine forest (Code Natura 2000: 95.40), Aleppo pine sub-zone (Code Natura 2000: 42.84). It is situated on calcareous, arid and stony soil in southwestern France, near Fontcouverte, on the Alaric Mountain, Corbières, Aude, France ( $43^{\circ} 10^{\prime} 00^{\prime \prime} \mathrm{N}, 02^{\circ} 35^{\prime} 00^{\prime}$ E) (FON). The altitude is about $100 \mathrm{~m}$. The arboreal vegetation consists of Pinus halepensis, Quercus ilex and Cupressus sempervirens. The shrub stratum is composed of Buxus sempervirens, Quercus coccifera and Cistus spp. The herbaceous cover is irregular, essentially composed of the Mediterranean indicatory Brachypodium ramosum.

Lacewings were collected by day with a hand net or by beating when the insects were not able to fly because of the cold weather. Twenty-three samples were taken every month or twice a month from June 1985 to July 1986 (Canard, 1987).

\subsubsection{Mediterranean orophilous maquis}

An oro-Mediterranean moorland maquis (code Natura 2000: 40.90) was surveyed near Ghisoni, Corse-du-Nord, France $\left(42^{\circ}\right.$ 06'00" $\left.\mathrm{N}, 09^{\circ} 13^{\prime} 00^{\prime} \mathrm{E}\right)$ (GHI) in July 1999, taking into account the tree and shrub foliage on the fringe of Quercus ilex and Quercus rotundifolia woods (code Natura 2000: 93. 40). The collecting method was hand-net sweeping in places situated between 700 and $1000 \mathrm{~m}$ altitude by day.

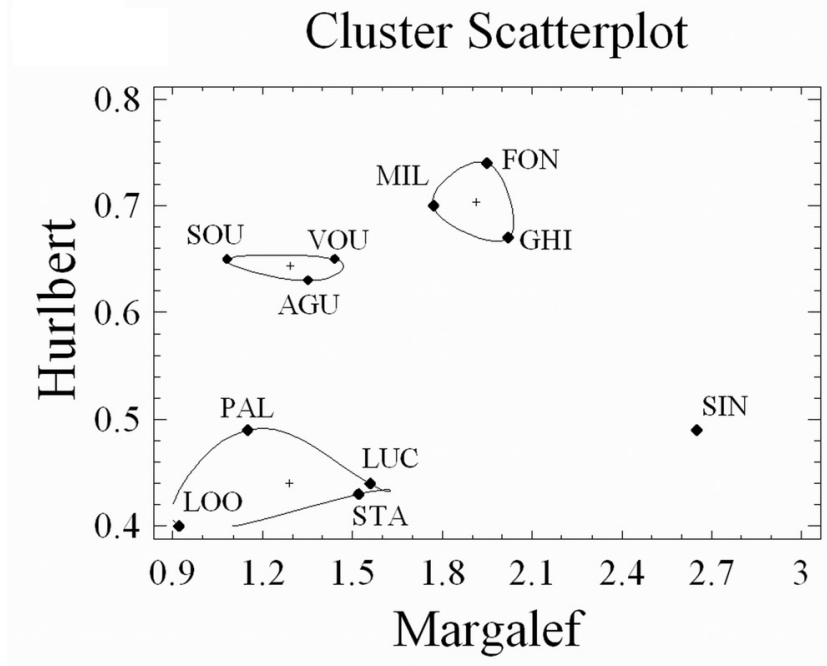

Figure 2. Cluster results of the position of each biotope in threedimensional space $\mathrm{I}_{\mathrm{M}}, \mathrm{H}^{\prime}$ and $\mathrm{E}_{\mathrm{H}}$. The projection is in the plane [Margalef's index $\mathrm{I}_{\mathrm{M}}$, Hurlbert's index $\mathrm{E}_{\mathrm{H}}$ ]. This proximity analysis confirms the high sensitivity of these parameters to the structure of the various green lacewing assemblages studied. AGU = Aguistri, FON = Fontcouverte, $\mathrm{GHI}=$ Ghisoni, $\mathrm{LOO}=$ Loos-en-Gohelle, MIL = Millau, PAL = Paleochora, $\mathrm{SIN}=$ Sinaia, $\mathrm{SOU}=$ Souda, $\mathrm{STA}=$ Saint Aubin Island, VOU = Vouvray.

\subsubsection{Continental mountain forest}

A mountain forest environment was investigated in the continental region, mountain stratum of spruce acidophilous forest (Code Natura 2000: 94.10), sub-alpine picea zone (Code Natura 2000: 42.21). The site is located in the Transylvanian Alps, near Sinaia, about $110 \mathrm{~km}$ northwest of Bucharest and $60 \mathrm{~km}$ south of Brasov, Romania (45 $21^{\circ}$ '00” N, 25 33'00” E) (SIN), at an altitude of $810 \mathrm{~m}$, near two small brooks in the Prahova valley. The vegetation consists of an arboreal canopy of Fagus sylvatica and the conifers Picea excelsa, Abies alba and Pinus silvestris, associated with diversified shrubs such as Alnus incana, and the herbaceous ground cover typical of forest glades.

Adult lacewings were collected by a light trap with a mercury vapor bulb of 200 watts. The traps were visited two or three times a week from May to October 1988 (Paulian et al., 2001).

\section{RESULTS AND DISCUSSION}

The results are presented in Table I (quantitative data) and in Table II (calculated values of indices). Whatever the number of species occurring and their distribution, the size of the collected samples, including the smallest - the Corsican one (GHI) - allows us to assess index values precise enough to compare the habitats between them. A proximity analysis (cluster scatterplot) of Margalef's and Hurlbert's indices relative to the different locations confirms the high sensitivity of these parameters to the structure of the various assemblages studied (Fig. 2). It is evident that the Romanian montane forest biotope (SIN) is conspicuously different: the number of rare species was fairly high, and seven species were abundant in which two 
Table I. Adult green lacewing specimens collected in various sites: AGU = Aguistri, FON = Fontcouverte, GHI = Ghisoni, LOO = Loos-enGohelle, MIL = Millau, PAL = Paleochora, $\mathrm{SIN}=$ Sinaia, $\mathrm{SOU}=$ Souda, STA = Saint-Aubin Island, VOU = Vouvray.

SPECIES \ SITES

Brinckochrysa nachoi Monserrat, 1977

Chrysopa dubitans McLachlan, 1887

Chrysopa formosa Brauer, 1850

Chrysopa nigricostata Brauer 1850

Chrysopa pallens (Rambur, 1838)

Chrysopa perla (Linnaeus, 1758)

Chrysopa phyllochroma Wesmael, 1841

Chrysopa viridana Schneider, 1845

Chrysopa walkeri McLachlan, 1893

Chrysoperla carnea s. l. (Stephens, 1836)

| Chrysoperla carnea s. s.

| Chrysoperla affinis (Stephens, 1836)

| Chrysoperla lucasina (Lacroix, 1912)

Chrysoperla mediterranea (Hölzel, 1972)

Chrysoperla mutata (McLachlan, 1898)

Chrysotropia ciliata (Wesmael, 1841)

Cunctochrysa albolineata (Killington, 1935)

Cunctochrysa baetica (Hölzel, 1972)

Dichochrysa abdominalis (Brauer, 1856)

Dichochrysa clathrata (Schneider, 1845)

Dichochrysa flavifrons (Brauer, 1850)

Dichochrysa genei (Rambur, 1842)

Dichochrysa iberica (Navás, 1903)

Dichochrysa inornata (Navás, 1901)

Dichochrysa picteti (McLachlan, 1880)

Dichochrysa prasina (Burmeister, 1839)

Dichochrysa ventralis (Curtis, 1834)

Dichochrysa zelleri (Schneider, 1851)

Hypochrysa elegans (Burmeister, 1839)

Italochrysa italica (Rossi, 1790)

Nineta flava (Scopoli, 1763)

Nineta inpunctata (Reuter, 1894)

Nineta pallida (Schneider, 1846)

Nineta principiae Monserrat, 1980

Nineta vittata (Wesmael, 1841)

Nothochrysa capitata (Fabricius, 1793)

Nothochrysa fulviceps (Stephens, 1836)

Peyerimhoffina gracilis (Schneider, 1841)

Rexa lordina Navás, 1919

Rexa raddai (Hölzel, 1966)

Suarius nanus (McLachlan, 1893)

Total

$\begin{array}{cccc}\text { LOO } & \text { AGU } & \text { PAL } & \text { SO } \\ & 3 & 6 & 39\end{array}$

16

1

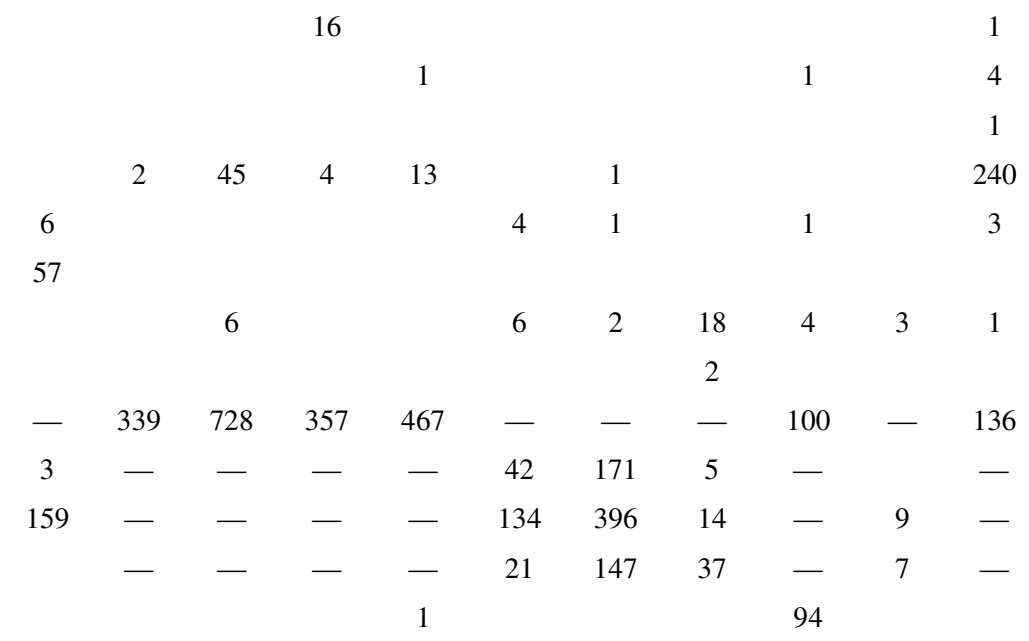

1

1

1

1

8

1

1

15

$\begin{array}{ccccccccc} & 97 & 18 & 4 & & & & & \\ 1 & 28 & 1417 & 626 & 1041 & 19 & 34 & 16 & 8 \\ & 11 & 15 & 14 & & & & & \end{array}$

130

$\begin{array}{ccccccc} & & & 5 & 84 & & 2 \\ 1 & 22 & & 1 & 3 & 45 & 3 \\ 1 & 2413 & 34 & & 85 & 42 & 42\end{array}$

$\begin{array}{llll}185 & 302 & 469 & 185\end{array}$

2

14

1

13

1 
Table II. Biodiversity indices of samplings collected in various sites: AGU = Aguistri, FON = Fontcouverte, GHI = Ghisoni, LOO = Loos-enGohelle, MIL = Millau, PAL = Paleochora, SIN = Sinaia, SOU = Souda, STA = Saint-Aubin Island, VOU = Vouvray. Italic types: observed value, in parenthesis: SD and in square brackets: CT1-CT2.

\begin{tabular}{|c|c|c|c|c|c|c|c|c|c|c|c|}
\hline Site & LOO & AGU & PAL & SOU & LUC & VOU & STA & MIL & FON & GHI & SIN \\
\hline $\begin{array}{l}\text { Richness } \\
\text { of Margalef }\end{array}$ & $\begin{array}{c}0.92 \\
(0.131)\end{array}$ & $\begin{array}{c}1.35 \\
(0.119)\end{array}$ & $\begin{array}{c}1.15 \\
(0.062)\end{array}$ & $\begin{array}{c}1.08 \\
(0.025)\end{array}$ & $\begin{array}{c}1.56 \\
(0.142)\end{array}$ & $\begin{array}{c}1.44 \\
(0.110)\end{array}$ & $\begin{array}{c}1.52 \\
(0.187)\end{array}$ & $\begin{array}{c}1.77 \\
(0.140)\end{array}$ & $\begin{array}{c}1.94 \\
(0.137)\end{array}$ & $\begin{array}{c}2.02 \\
(0.155)\end{array}$ & $\begin{array}{c}2.65 \\
(0.205)\end{array}$ \\
\hline$\left(\mathrm{I}_{\mathrm{M}}\right)$ & \multicolumn{11}{|c|}{$[0.55-0.92][0.90-1.35][1.02-1.15]$} \\
\hline $\begin{array}{l}\text { Diversity } \\
\text { of Shannon }\end{array}$ & $\begin{array}{c}0.80 \\
(0.059)\end{array}$ & $\begin{array}{c}1.48 \\
(0.029)\end{array}$ & $\begin{array}{c}1.14 \\
(0.019)\end{array}$ & $\begin{array}{c}1.43 \\
(0.020)\end{array}$ & $\begin{array}{c}1.17 \\
(0.015)\end{array}$ & $\begin{array}{c}1.50 \\
(0.061)\end{array}$ & $\begin{array}{c}1.10 \\
(0.030)\end{array}$ & $\begin{array}{c}1.76 \\
(0.050)\end{array}$ & $\begin{array}{c}1.95 \\
(0.038)\end{array}$ & $\begin{array}{c}1.72 \\
(0.116)\end{array}$ & $\begin{array}{c}1.52 \\
(0.039)\end{array}$ \\
\hline$\left(\mathrm{H}^{\prime}\right)$ & \multicolumn{11}{|c|}{$[0.67-0.90][1.42-1.53][1.10-1.17][1.39-1.47][$} \\
\hline $\begin{array}{l}\text { Equitability } \\
\text { of Hurlbert }\end{array}$ & $\begin{array}{c}0.40 \\
(0.048)\end{array}$ & $\begin{array}{c}0.63 \\
(0.028)\end{array}$ & $\begin{array}{c}0.49 \\
(0.014)\end{array}$ & $\begin{array}{c}0.65 \\
(0.011)\end{array}$ & $\begin{array}{c}0.44 \\
(0.021)\end{array}$ & $\begin{array}{c}0.65 \\
(0.035)\end{array}$ & $\begin{array}{c}0.43 \\
(0.035)\end{array}$ & $\begin{array}{c}0.70 \\
(0.030)\end{array}$ & $\begin{array}{c}0.74 \\
(0.025)\end{array}$ & $\begin{array}{c}0.67 \\
(0.062)\end{array}$ & $\begin{array}{c}0.49 \\
(0.020)\end{array}$ \\
\hline$\left(\mathrm{E}_{\mathrm{H}}\right)$ & {$[0.36-0.55$} & $61-0.7$ & $47-0.5$ & $.63-0.6$ & $.44-0.5$ & $0.60-0.7$ & $0.44-0.5$ & $0.67-0$ & $0.72-$ & 0.54 & $0.48-0.56]$ \\
\hline
\end{tabular}

were dominant, namely Cunctochrysa albolineata (Killington, 1935), 48.1\% and Chrysopa pallens (Rambur, 1838), 26.9\%. The Mediterranean biotopes, together with the Ligerian meadow (VOU), are characterized by an equitability always higher than 0.63 , whatever the number of collected species. The wild Mediterranean biotopes represented by the maquis moorland (GHI), the typical Aleppo pine forest (FON) and the calcareous slopes (MIL) seem to be rich and well-balanced biotopes, delimited by a higher number of occurring species $\left(\mathrm{I}_{\mathrm{M}}>1.7\right)$. Contrarily, these biotopes are better than the two insecticide-free olive groves (AGU and $\mathrm{SOU}$ ) $\left(\mathrm{I}_{\mathrm{M}}<1.4\right)$. Besides, the continental wet montane forest of Sinaia (SIN) is different from the other biotopes because of its highest faunistic richness.

Figure 3 clearly shows a correlation between the values of Shannon's and Hurlbert's indices. It gives a diagrammatic typological approach of the biotopes. In the scanty agro-ecosystem (LOO) and also at a lower level in the sites strongly altered by agricultural practices such as the treated olive grove (PAL), the faunistic richness was low. In any case, one (or two) species was dominant, whilst the others were rare $\left(\mathrm{E}_{\mathrm{H}}<0.5\right)$. The regularly flooded meadows (STA) were dominated (colonized every year?) by the ubiquitous Chrysoperla carneacomplex species whilst the olive grove assemblages PAL and LUC showed dominance of Dichochrysa flavifrons (Brauer, 1850) and D. prasina (Burmeister, 1839), respectively.

The green lacewing assemblages are generally much better balanced in agricultural landscapes when they are seldom farmed or abandoned, such as the olive culture in Agitri island $(\mathrm{AGU})$ and the fallow meadows of the Loire valley (VOU). Common green lacewings nevertheless remain dominant $\left(\mathrm{E}_{\mathrm{H}}>0.63\right)$. The same pattern is also displayed in all sites harboring sub-spontaneous vegetations with complex structure such as the arboreal slopes of Millau (MIL), moorland maquis of Ghisoni (GHI) and hilly thin pine forest of Fontcouverte (FON).

\section{CONCLUSION}

The literature of green lacewing ecology is abundant; for instance, Zeleny (1994) gave rich information on chrysopid

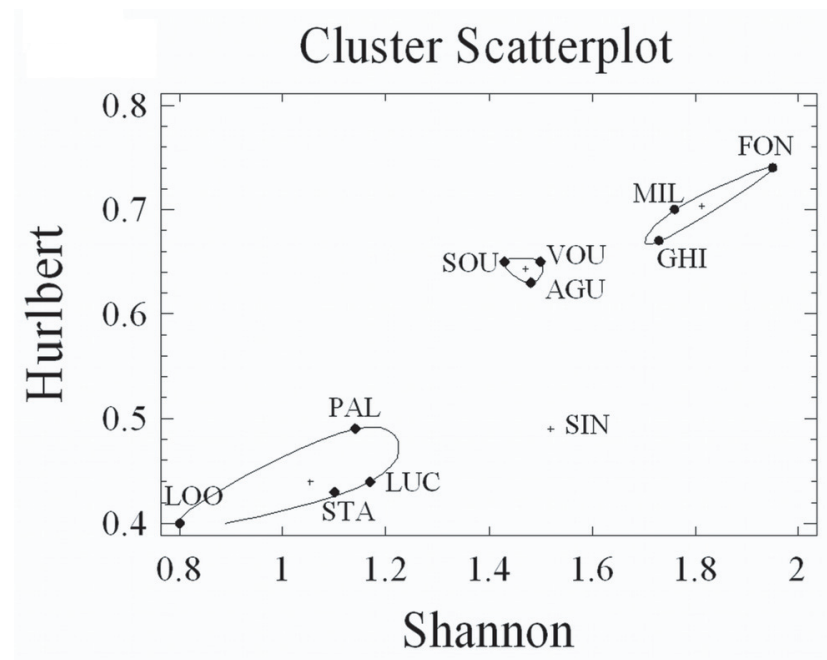

Figure 3. Cluster results of the position of each biotope in threedimensional space $\mathrm{I}_{\mathrm{M}}, \mathrm{H}^{\prime}$ and $\mathrm{E}_{\mathrm{H}}$. The projection is in the plane [Shannon's index H', Hurlbert's index $E_{H}$ ]. This figure clearly shows a correlation between the values of Shannon's and Hurlbert's indices, and it gives a diagrammatic typological approach for typifying ecological landscapes. AGU = Aguistri, FON = Fontcouverte, $\mathrm{GHI}=$ Ghisoni, LOO $=$ Loos-en-Gohelle, MIL = Millau, PAL $=$ Paleochora, SIN = Sinaia, $\mathrm{SOU}=$ Souda, $\mathrm{STA}=$ Saint-Aubin Island, VOU $=$ Vouvray.

occurrence in west-Palaeartic temperate forest and derived biotopes, Monserrat and Marín (1994) on substrate specificity and Szentkirályi (2001) on habitat relationships. However, these contributions do not quantify indicators of biodiversity.

The method consisting of establishing average diversity indices together with their confidence intervals allows unambiguous comparisons between assemblages of green lacewings from different biotopes. Furthermore, it is possible to characterize the state of these polyvalent predators as a function of different abundance and diversity, and this state can be a standard of value of good ecological function in ecosystems. Concerning agricultural consultation, such an approach to analysis and management is promising for all organizations responsible 
for future agriculture which must become and remain sustainable and respectful of the planet's resources.

Acknowledgements: This study was partially supported by 'L'Ablette Angevine' (Angers, France) as a grant to J. Villenave. A shorter version of the present work was presented as a poster in the Third International Plant Protection Symposium at Debrecen University, Debrecen, Hungary, 15-16 October 2003: From Ideas till Implementation. Challenge and Practice of Plant Protection at the Beginning of the 21st Century. The authors are further indebted to Dr Andy Whittington (Edinburgh, Scotland, UK) and an anonymous reviewer for linguistic improvements of the manuscript.

\section{REFERENCES}

Alrouechdi K., Lyon J.-P., Canard M., Fournier D. (1980) Les Chrysopides (Neuroptera) récoltés dans une oliveraie du Sud-Est de la France, Acta Oecol. / Oecol. Appl. 1, 173-180.

Anonymous, Ramsar brochure or "flyer", first published in February 1996 and revised in February 1998 and April 2000, Dwight Peck, Ramsar, Iran.

Beisel J.-N., Thomas S., Usseglio-Polatera P., Moreteau J.-C. (1997) Assessing changes in community structure by dominance indices: a comparative analysis, J. Freshwater Ecol. 11, 291-299.

Canard M. (1987) Cycle annuel et place de Chrysoperla mediterranea (Hölzel) (Neuroptera: Chrysopidae) en forêt méditerranéenne, Neuroptera Int. 4, 279-285.

Canard M., Laudého Y. (1977) Les Névroptères capturés au piège de McPhail dans les oliviers en Grèce. 1. L'île d'Aguistri, Biologia Gallo-Hellenica 7, 65-75.

Canard M., Neuenschwander P., Michelakis S. (1979) Les Névroptères capturés au piège de McPhail dans les oliviers en Grèce. 3. La Crète occidentale, Ann. Soc. Entomol. Fr. (N.S.) 15, 607-615.

Corillion R. (1995) Le lit mineur de la Loire : climatologie et végétation, C.R. Acad. Agric. France 81, 67-82.

Duelli P. (1997) Biodiversity evaluation in agricultural landscapes: an approach at two different scales, Agr. Ecosyst. Environ. 62, 81-91.

Efron B. (1982) The Jackknife, the Bootstrap and Other Resampling Plans, SIAM, CBMS-NSF Regional Conference Series in Appied Mathematics, SIAM, Philadelphia, Vol. 38.
Efron B., Tibshirani R.J. (1993) An Introduction to the Bootstrap, Chapman and Hall, New York.

Lawton J.H., Brown V.K. (1993) Redundancy in ecosystems, in: Schulze E.D., Mooney H.A. (Eds.), Biodiversity and Ecosystem Function, Springer-Verlag, New York, USA, pp. 255-270.

Manly B.F.J. (1991) Randomization and Monte Carlo methods in biology, Chapman and Hall, New York.

Monserrat V.J., Marín F. (1994) Substrate specificity of Iberian chrysopidae (Insecta: Neuroptera), Acta Oecol. 15, 119-131.

Naeem S., Li S. (1997) Biodiversity enhances ecosystem reliability, Nature 390, 507-509.

Neuenschwander P., Canard M., Michelakis S. (1981) The attractivity of protein hydrolysate baited McPhail traps to different chrysopid and hemerobiid (Neuroptera) species in a Cretan olive orchard, Ann. Soc. Entomol. Fr. (N.S.) 17, 213-220.

Paulian M., Canard M., Thierry D., Ciubuc C. (2001) Survey of green lacewings in southern Transylvania, Romania, with some ecological notes (Neuroptera: Chrysopidae), J. Neuropter. 3, 25-31.

Paulian M., Thierry D., Deutsch B., Canard M. (2003) Quantifying biodiversity in ecosystems by green lacewing assemblages. II. An example for evidencing chronological changes in agroecosystems (Insecta: Neuroptera: Chrysopidae), in: From Ideas till Implementation. Challenge and Practice of Plant Protection in the Beginning of the 21st Century, Proceedings. 3rd International Plant Protection Symposium at Debrecen University, Debrecen, Hungary, 15-16 October 2003, pp. 248-249 (Summary).

Shannon C.E., Weaver W. (1963) The Mathematical Theory of Communication, University Illinois Press, Urbana, Illinois, USA.

Stelzl M., Devetak D. (1999) Neuroptera in agricultural ecosystems, Agr. Ecosys. Environ. 24, 305-321.

Szentkirályi F. (2001) Ecology and habitat relationships; in: McEwen P.K., New T.R., Whittington A.E. (Eds.), Lacewings in Crops Environment, Cambridge University Press, Cambridge, UK, pp. 82-115.

Trouvé C., Thierry D., Canard M. (2002) Preliminary survey of the lacewings (Neuroptera: Chrysopidae, Hemerobiidae) naturally occurring in agroecosytems in northern France, with phenological notes, Acta Zool. Acad. Sci. Hung. 47 (Suppl. 2), 359-369.

Zeleny J. (1994) Chrysopid occurrence in west-Palaearctic temperate forests and derived biotopes, in: Canard M., Séméria Y., New T.R. (Eds.), Biology of Chrysopidae, Dr W. Junk Publ., The Hague, NL, pp. 151-160. 